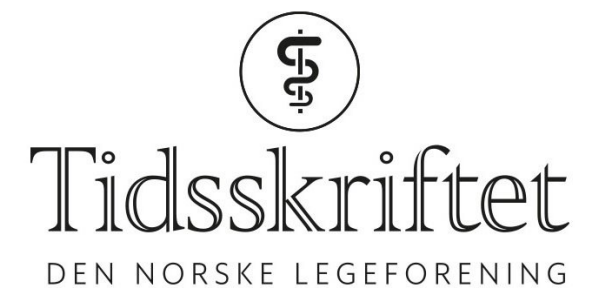

DEN NORSKE LEGEFORENING

\title{
Ikke undervurder pasientene
}

DEBATT

\section{DANIEL SØRLI}

E-post: daniel.sorli@gmail.com

Daniel Sørli er tidligere fastlege, nå lege og daglig leder i Dr.Dropin AS.

Forfatter har fylt ut ICMJE-skjemaet og oppgir følgende interessekonflikter: Han er daglig leder og eier aksjer i Dr. Dropin AS.

Overdiagnostikk og overbehandling er en utfordring innen norsk helse, men friske folk blir ikke syke fordi de vil bruke 6oo kroner på å spare 150 .

I sitt innlegg «Legeetikk på billigsalg» problematiserer lege Nils Petter Sørung at pasienter kan opptjene Cashpoints hos flyselskapet Norwegian ved legebesøk hos Dr. Dropin. Sørung gjentar argumentasjonen til Rådet for legeetikk, som i april 2019 vedtok å be oss om å stoppe tilbudet.

Rabattordninger er overalt, også innen helsetjenester. Mange aktører har tilbud der pasienten får den neste timen billigere. I tillegg kommer medlemsordningene til andre etablerte private helseaktører. Videre kan du allerede i dag bruke kredittkort med ulike typer fordeler for å betale ditt neste legebesøk. Bruker du Eurobonus Mastercard er det prinsipielt ingen forskjell på dette og Dr.Dropins tilbud. Du kjøper en legetjeneste, drar kortet og tjener opp bonuspoeng.

Kjernen i denne saken er om tilbudet til Dr.Dropin fører til at pasienter får legehjelp når de egentlig ikke trenger det. Svaret er nei. Det stemmer ikke at folk er villig til å betale 600 kroner for legehjelp de ikke trenger fordi de vil tjene 150 kroner. Ingen av dem som har benyttet seg av tilbudet til Dr. Dropin, har kommet uten et reelt behov for legehjelp. Nils Petter Sørung undervurderer pasientene.

Ingen av dem som har benyttet seg av tilbudet til Dr.Dropin, har kommet uten et reelt behov for legehjelp

Vi stiller også spørsmål ved hvor Rådet for legeetikk forankrer sin avgjørelse i de etiske reglene for leger. Den som går inn i detaljene, vil se at Rådet viser til kapittel III, men ikke til noen konkret paragraf eller annen bestemmelse i sitt vedtak. Dette er betenkelig. Rådet har en viktig rolle, og de etiske reglene for leger er høyt respektert. Både i Dagsnytt 18 og i vårt skriftlige tilsvar til Rådet for legeetikk har vi oppfordret rådet til å forankre sitt vedtak ved å vise til eksakt hvilken bestemmelse i de etiske reglene som de mener Dr.Dropin har brutt. Dette må være et minstekrav for seriøs saksbehandling.

Overdiagnostikk og overbehandling er en utfordring innen norsk helse. Modellen vår med en fastpris per legebesøk uavhengig av tidsbruk, prøver, diagnoser og oppfølging er en styrke og underbygger at vi kun ønsker å bistå våre pasienter når de selv har behov for helsetjenester. 
Mange av pasientene som kommer til Dr.Dropin, er fortvilet over andre primærhelsetilbuds manglende tilgjengelighet: lang ventetid, korte åpningstider og liten grad av digitalisering. Dette er en debatt som burde få mer spalteplass i landets aviser, i tillegg til de enorme problemene med rekruttering i fastlegeordningen. Ikke undervurder pasientene og fokuser heller på de virkelige utfordringene.

Publisert: 7. oktober 2019. Tidsskr Nor Legeforen. DOI: 10.4045/tidsskr.19.0582

Mottatt 13.9.2019, godkjent 16.9.2019.

C Tidsskrift for Den norske legeforening 2020. Lastet ned fra tidsskriftet.no 